\title{
MODELOS: DO GLAMOUR À ESCRAVIDÃO CONTEMPORÂNEA
}

\author{
Roberta Portella Franco ${ }^{1}$ \\ Fernando de Oliveira Vieira ${ }^{2}$ \\ Mariana Rambaldi ${ }_{-}^{3}$
}

\section{RESUMO}

O presente estudo teve como objetivo principal avaliar a analogia à escravidão contemporânea na vida das modelos de moda. Para alcançar tal objetivo, foi realizada uma pesquisa de campo qualitativa, na qual cinco modelos brasileiras, com mais de três anos de carreira e com experiência internacional, foram entrevistadas. A partir dos resultados obtidos nas entrevistas, observou-se que há indícios de escravidão contemporânea na carreira de modelo, tais como jornada exaustiva, condições degradantes e restrição de locomoção.

Palavras-Chave: Escravidão Contemporânea; Jornada Exaustiva; Condições Degradantes; Restrição de Locomoção; Vida de Modelo.

\section{MODELOS: DEL GLAMOUR A LA ESCLAVITUD CONTEMPORÁNEA}

\section{RESUMEN}

El presente estudio tuvo como objetivo evaluar la analogía con la esclavitud contemporánea en la vida de los modelos de moda. Para lograr este objetivo, se realizó una investigación de campo cualitativa, en la que se entrevistó a cinco modelos brasileños, con más de tres años de carrera y con experiencia internacional. A partir de los resultados obtenidos en las entrevistas, se observó que hay signos de esclavitud contemporánea en la carrera de modelaje, como horas de trabajo agotadoras, condiciones degradantes y movilidad restringida.

\footnotetext{
${ }^{1}$ Graduada em Administração pela Universidade Federal Fluminense, Niterói - RJ, Brasil.

2 Doutor em Educação pela Universidade Metodista de Piracicaba, Piracicaba - SP, Brasil.

${ }^{3}$ Psicóloga e Mestranda em Administração pela Universidade Federal Fluminense, Niterói - RJ, Brasil.
} 
Palabras clave: Esclavitud contemporánea; Viaje exhaustivo; Condiciones degradantes; Restricción de locomoción; Modelo de vida.

\section{MODELS: FROM GLAMOR TO CONTEMPORARY SLAVERY}

\section{ABSTRACT}

The present work is aimed to evaluate contemporary enslavement in the life of fashion models. To achieve this goal, a qualitative field of research was conducted, in which five brazilian models, all with careers of more than three years and having international experience, were interviewed. From the results compiled in the interviews, it was observed that there are indications of contemporary enslavement in the modeling career such as exhausting journey, degrading living conditions and a lack of mobility.

Keywords: Contemporary Slavery; Exhausting Journey; Degrading Living Conditions; Lack of Mobility; Model Life.

\section{INTRODUÇÃo}

O mundo moderno vem passando por grandes transformações. 0 consumo está cada vez mais acelerado, as relações cada vez mais efêmeras e, muitas vezes, desumanas. O livro "Vida Para Consumo", que foi escrito em 2007 por Zygmunt Bauman, expõe uma trágica realidade da sociedade líquido-moderna: a transformação dos indivíduos em mercadorias, em última análise. O autor aborda os impactos dessa transformação em diversas áreas da vida. Uma dessas áreas é a da moda. Bauman tenta mostrar que os sujeitos, de uma maneira geral, precisam se moldar e se adequar à realidade dessa sociedade descartável, para que consigam chamar atenção e se manterem em uma boa posição nas "prateleiras". A obra deste autor é de grande importância para nós, que nos sentimos estimulados e forçados a cumprir com os quesitos impostos pelo mercado, ou seja, ser uma beleza atraente e desejável que faz de tudo para que tenha grande valor no mercado.

Ainda existe muita omissão, por parte das modelos, em falar abertamente sobre como ocorrem os processos de seleção para um trabalho, o tratamento e condições que são dadas às 
modelos. Por isso, o estudo busca entender se chega a haver trabalho análogo à escravidão, em que há controle do indivíduo sobre o outro, apropriação da força de trabalho e imposição das condições pela violência ou ameaça (BALES; ROBBINS, 2001).

Identificar quais aspectos criam a insatisfação de modelos poderá fornecer informações relevantes para, quem sabe, gestores de agências e donos de marcas atualizarem suas formas de gerir essas "mercadorias", ou melhor, essas pessoas. Tais mudanças seriam benéficas tanto para a modelo, quanto para a agência e cliente.

As pressões constantes pela magreza podem levar o indivíduo a transtornos alimentares, e em alguns casos extremos, ao óbito, como é o caso da modelo Ana Carolina Reston, que desfaleceu aos 21 anos de anorexia nervosa, com apenas 40kg (VAL; CARVALHO; CAMPOS, 2015).

A profissão de modelo é regulamentada no ordenamento brasileiro. Porém, muitas agências burlam a lei. Isso ocorre porque a parte mais frágil na relação, a jovem modelo, não conhece seus direitos, ou ainda, tem medo de reivindicá-los e perder trabalhos. A exigência de modelos cada vez mais magras deve ser tratada também na esfera trabalhista, pois se há possiblidade do reconhecimento do vínculo empregatício com agências, o descumprimento de direitos constitucionais pode gerar indenização por dano moral na Justiça do Trabalho (MESQUITA, 2017).

Diante disso, a conclusão a que se chega é de que os profissionais que trabalham na área da moda devem se adequar às leis trabalhistas que existem no Brasil. 0 respeito à dignidade da pessoa humana, bem como o respeito à pessoa em desenvolvimento, deve servir de base para o tratamento dado pelas agências às modelos profissionais.

Portanto, a partir dessa investigação, observamos a relação "empregador" - "empregado", estabelecendo um paradigma que expõe e reavalia o modelo de ética usado nos ambientes de trabalho que envolve a indústria da moda, para inclusive conseguir determinar se há de fato ou não uma naturalização de comportamentos violentos à moral do subordinado. 
Encontra-se muito pouco e também de difícil acesso um estudo mais aprofundado sobre as consequências desse modelo de trabalho e a concepção de produtividade com um foco nas modelos. Tratando-se de um tema recorrente e importante no cenário contemporâneo, um estudo que propõe uma junção de uma série de observações poderia trazer à luz a fala de profissionais da moda para uma compreensão maior da carreira.

A vida de uma modelo de moda é vista, na maioria das vezes, como luxuosa. Bastaria, contudo, apenas uma caminhada na passarela ou grandes poses para fotos para que muitas delas alcançassem esse patamar? Qual o preço que se paga? Em que medida a profissão das modelos, lidando de forma tão forte com a "promoção da vida", se aproxima de uma relação de escravidão contemporânea? Até que ponto ser uma beleza vendável, nesse meio, não se torna manipulação da consciência? Por meio dessa pesquisa, poderemos analisar a forma de gerir modelos.

O objetivo principal foi estudar as condições da vida de modelo de moda, buscando saber se existe traço de escravidão contemporânea na profissão.

\section{ESCRAVIDÃO CONTEMPORÂNEA}

De acordo com Kevin Bale e Peter T. Robbins (2001), a escravidão é um modelo de relação social e econômica, que muda e evolui de acordo com necessidades da humanidade. Baseado em um fundamento de exploração humana, a escravidão tem episódios demarcados por mudanças legislativas, que nem sempre acompanham a evolução do que também se entende como direito humano.

Os estudos e diversos documentos de órgãos ligados ao combate do trabalho escravo (ONU - Organização das Nações Unidas, OIT - Organização Internacional do Trabalho, MTE Ministério do Trabalho e Emprego, CPT - Comissão da Pastoral da Terra, MPT - Ministério Público do Trabalho e ONG - Organizações Não Governamentais, tais como a Repórter Brasil) apontam que o quadro é alarmante, com previsão de 21 milhões de pessoas em situação considerada análoga à escravidão, o que gera cerca de US\$ 150 bilhões de lucros obtidos por meio desse modo (BASTOS, 2016; OIT, 2015). 
Embora esses números sejam apenas uma previsão, dadas as dificuldades para se verificar a procedência de muitos tipos de denúncia, em lugares remotos ou de difícil acesso, estima-se que tal previsão esteja alicerçada nas seguintes demarcações:

a) Ásia - 10 milhões, com destaque para China e Índia; b) América Latina e Caribe - 1,3 milhões; c) África - 700 mil; d) 400 mil nos países industrializados (OIT, 2005). Nesse sentido, Gomes (2012, pág. 169) defende que, no Brasil, deve-se ter entre 100 e 200 mil trabalhadores em regime de escravidão contemporânea. De 1995 a 2006, Antero (2008) registra que mais de 21 mil trabalhadores escravizados foram resgatados, no nosso país.

Se, no passado, o que caracterizava a escravidão, era o trabalho forçado, a privação de liberdade do sujeito escravizado e o endividamento do indivíduo (OIT, 2015), hoje, o debate acerca de seu diagnóstico gira em torno também de outros elementos classificados como "trabalho análogo à escravidão" ou "trabalho escravo contemporâneo" (GOMES, 2012). De acordo com Gomes (2012), os indicadores que podem auxiliar a identificar um trabalho nessas condições são: a) mecanismos de sujeição do trabalhador; b) isolamento geográfico ou não; c) ser ou não estrangeiro; d) controle por meio de violência física ou simbólica; e) endividamento obrigatório do escravizado pelo patrão; f) condições degradantes ou humilhantes para a pessoa humana (dormindo em barracas de plástico, sem água potável, comendo comida estragada etc).

De acordo com Antero (2008), há, ainda, outros elementos, que podem caracterizar o trabalho escravo contemporâneo, de acordo com o MTE, que devem guiar a fiscalização: a) restrição à liberdade dos trabalhadores; b) vigilância armada;

c) situação geográfica da propriedade (por intermédio de GPS); d) identificação das condições de trabalho; e) atividade econômica; f) equipamentos de proteção; g) acidentes e doenças; h) alimentação e fornecimento de água; i) jornada/descanso; j) sistema de barracão (servidão por dívida); k) retenção dolosa de salários; l) total informalidade dos contratos de trabalho; m) violência cometida por "gato"(intermediário) ou proprietário ou a mando desses.

Relatórios de fiscalização tem servido para o diagnóstico de analogia à escravidão, sem haver necessidade de identificação de todos esses itens, para tal configuração.

Avanços tem sido registrados por meio desses documentos. No entanto, apesar do visível progresso, no campo da fiscalização, as ações ainda parecem inócuas, no que tange 
tanto a políticas de estado, que inibam a reincidência, quanto no aspecto acadêmico, que auxilie a explicar causas de continuidade da violência e/ou de efetividade das ações.

Dos séculos XVI ao XIX, a escravidão era uma prática legal. O escravo, propriedade privada de um patrão, era forçado a trabalhar e tinha sua liberdade cerceada. A partir da abolição formal da escravatura e de sua criminalização, muitos movimentos tem denunciado que tal regime não foi extirpado, mas, ao contrário, tem se mantido tanto sob as mesmas características, em regiões mais remotas, quanto sob outros disfarces de organização do trabalho, nas sociedades hodiernas.

No nível acadêmico, estudos sobre esse tipo de violência, tem sido registrados sob as perspectivas de "trabalho escravo contemporâneo", "trabalho análogo à escravidão", "trabalho forçado" ou neoescravidão", em diferentes campos de conhecimento, desde o Direito, Ciências Sociais, Psicologia, Administração, Economia, dentre outros (ANTERO, 2008; GOMES, 2012; LEÃO, 2015). No nível das ações, formalizam-se políticas de Estado e de outros órgãos da sociedade civil organizada, na luta à erradicação dessa prática (OIT - Organização Internacional do Trabalho; Ministério da Economia (extinto MTE - Ministério do Trabalho e Emprego; MPT - Ministério Público do Trabalho; Pastoral da Terra; ONG Repórter Brasil etc). Há banalização de diversos tipos de violência, tais como a injustiça social (DEJOURS, 2000), o assédio moral (BARRETO \& HELOANI, 2015) e assédio organizacional (ARAÚJO, 2012) e o trabalho escravo contemporâneo como método de gestão (MASCARENHAS, DIAS e BATISTA, 2015). O quadro tem sido sustentado por um discurso defensor do desenvolvimento do Capital a qualquer preço. Desconsideram-se direitos básicos de dignidade à vida humana. Produzem-se subjetividades apáticas a perversidades, inclusive contra si próprias.

Se, por um lado, a literatura sobre "trabalho escravo contemporâneo" caracteriza e denuncia contradições sociais, que permitem a manutenção do sistema ou seu reaparecimento sob outros disfarces, por outro, cumpre estudar cenários atuais do mundo do trabalho, que ampliem uma possível identificação da supracitada prática, em ocupações que, em tese, não estariam vulneráveis ao cerceamento de liberdade, à escravidão por dívida ou a outro indicador de demarcação do tipo convencional de escravidão. As discussões atuais sobre o tema jogam ainda mais luz aos indicadores "jornada exaustiva" e "condições degradantes". Isso porque a publicação da Portaria no. 1.129/2017, de 13 de outubro de 
2017, traz mudanças significativas sobre o trabalho escravo. A principal delas refere-se à exclusão desses dois últimos supracitados indicadores como diagnosticadores do crime.

O trabalho escravo existe desde a antiguidade e, mesmo com a abolição, persiste na sociedade contemporânea (SENTO-SÉ, 2013). A escravidão continua presente. Não em sua forma tradicional, pré-capitalista, legalizada e permitida pelo Estado, mas como condição em que o trabalhador, na maioria das vezes, não é remunerado e tem sua vida controlada.

Podemos observar como é enraizado um modelo escravocrata, que sustenta toda uma sociedade. Se existiram mudanças em como a relação escravocrata se manifesta na contemporaneidade, talvez não tenha havido mudança em seu cerne. A escravidão de hoje é uma forma de exploração econômica, que se adaptou ao mundo global. Ainda que haja afirmações sobre a abolição do sistema escravista no país, segundo o Ministério do Trabalho, 49.942 foi o número de trabalhadores resgatados em condições análogas à escravidão entre 1998 e 2016 (MTE, 2016).

Ao longo dos anos, a escravidão é moldada e diversificada ao mundo atual, inclusive por carregar não só uma doutrina fixa, mas uma mentalidade estrutural, presente em pequenas nuanças do cotidiano. Ela persiste, ainda que tenha perdido o antigo conceito de propriedade do homem sobre homem e a imagem do escravo (figurativa) acorrentado a uma bola de ferro e morando em senzala, e de uma maneira mais versátil, pois o trabalho escravo constitui uma mão de obra disponível à vontade e que se adaptou ao mundo global, conforme afirma Sento-Sé (2013), quando diz que a escravidão está reproduzida pelas atuais condições da economia.

Quadro 1 - Comparativo escravidão: Ontem x Hoje

Ontem

\section{Propriedade legal Permitida}

Custo de Alto. A quantidade

aquisição de mão de escravos era de obra medida de riqueza
Hoje

Proibida

Muito baixo. Não há compra e muitas vezes gasta-se apenas 0 transporte 


$\begin{array}{lll}\text { Mão de obra } & \begin{array}{l}\text { Escassa. Dependia } \\ \text { do tráfico negreiro }\end{array} & \begin{array}{l}\text { Descartável. Devido ao contingente } \\ \text { de trabalhadores desempregados }\end{array} \\ \text { Relacionamento } & \begin{array}{l}\text { Longoríodo. } \\ \text { A vida inteira do } \\ \text { escravo e de } \\ \text { seus descendentes }\end{array} & \begin{array}{l}\text { Curto período. Terminado o serviço, } \\ \text { não é mais necessário prover o } \\ \text { sustento }\end{array}\end{array}$

Diferenças étnicas $\begin{aligned} & \text { Relevantes para } \\ & \text { a escravidão }\end{aligned}$

Ameaças,

Manutenção da $\begin{aligned} & \text { violênça psia cológica, } \\ & \text { ordem } \\ & \text { coerção física, punições e } \\ & \text { até assassinatos }\end{aligned}$

Pouco relevantes. Qualquer pessoa pobre e miserável pode que se tornar escrava, independente da cor de pele

Ameaças,

violência psicológica, coerção física, punições e até assassinatos

Fonte: Adaptado de BALES, K.; ROBBINS, P. T. No one shall be held in slavery or servitude: a critical analysis of international slavery conventions. 2001.

O conceito de escravidão está relacionado, sobretudo, à restrição da liberdade, e pouco diferem na escravidão histórica e contemporânea. As vítimas da escravidão contemporânea já sofriam antes com a pobreza, o desconhecimento da lei, o baixo nível ou ausência de escolaridade, com a inocência, além de serem vítimas do meio social (FIGUEIRA, 2000). De acordo com Barelli e Vilela (2000) essa ingenuidade e vontade de realizar o sonho de mudança de vida que tornam essas pessoas vulneráveis e acabam sendo seduzidas por falsas promessas.

O artigo 149 do Código Penal nos aponta o que seria o trabalho em condição análoga ao de escravo, citando condutas específicas: 1) trabalhos forçados; 2) jornada exaustiva; 3) condições degradantes de trabalho; 4) restrição, por qualquer meio, da locomoção por dívida contraída com o empregador ou outro meio. Cada um desses aspectos, embora descritos de forma distinta, estão por vezes presentes na realidade das relações de trabalho, sejam eles separados ou combinados entre si (MTE, 2016).

\section{TRABALHO FORÇADO}

No livro "Política", de Aristóteles, associa-se que o servo seria um instrumento para manutenção da Casa (Household) e, portanto, imprescindível para o sustento. Essa relação 
que atribui a particularidade do escravo como "propriedade animada", objetifica o humano como mecanismo operacional para geração de capital. É possível reconhecer uma premissa capitalista em primórdios das relações humanas.

O trabalho forçado ou trabalho compulsório, segundo a Organização Internacional do Trabalho, a OIT (2018), é o trabalho ou serviço imposto a uma pessoa a título de sanção penal mediante perda de direitos.

O trabalho forçado se refere a situações em que as pessoas são coagidas a trabalhar através do uso de violência ou intimidação, ou até mesmo por meios mais sutis, como servidão por dívidas, retenção de documentos de identidade ou ameaças de denúncia às autoridades de imigração. De acordo com a Convenção no 29 da OIT (adotada em 1930), trabalho forçado ou compulsório é "todo trabalho ou serviço exigido de uma pessoa sob a ameaça de uma sanção e para o qual a pessoa não se ofereceu espontaneamente". Ou seja, se o trabalhador não tem o poder de decisão sobre a aceitação do trabalho ou sobre sua permanência no mesmo, pode-se dizer que há trabalho forçado.

A coação, segundo o MTE (2016), pode ser moral, psicológica ou física. A moral seria quando o trabalhador é manipulado e seduzido a acreditar que deve permanecer no cargo. A coação psicológica seria quando há ocorrência de ameaças ou pressões psicológicas. E a coação física quando há de fato violência ou agressão.

\section{JORNADA EXAUSTIVA}

De acordo com Marinho e Vieira (2019), há incoerência quanto à compreensão do que é uma jornada de trabalho e sua relação com o tempo. 0 aumento na demanda de produtividade estabelece desequilíbrio entre a concepção de tempo e exigência no atual modelo de gestão. Funcionando como um processo de escalonamento, o aumento de demanda propulsiona um fenômeno como a jornada exaustiva, composta pela imbricação da intensidade e extensividade do trabalho. Dessa forma, ramificações implicam em horas que podem causar sequelas e malefícios físicos e provável redução de qualidade de vida e atenção. 
Uma relação que se baseia numa interpretação do abstrato não pode ser usada para mensurar efetividade já que se coloca num viés interpretativo e não concomitante ao factual. O modelo passa a ser favorável ao capital, que utiliza a premissa quantitativa para pressionar o trabalhador a cumprir funções e demandas de acordo com uma concepção não factual e coerente com a complexidade da função. A implicação da jornada exaustiva tem interferência no corpo, não só em nível mental, mesmo que igualmente prejudicial à saúde.

A exposição do empregado à jornada exaustiva de trabalho, em desacordo com limites previstos na legislação, é um dos fatores que levam à caracterização do trabalho análogo à escravidão. A jornada exaustiva, segundo o Tribunal Regional do Trabalho, deteriora as condições de trabalho e repercute negativamente na vida pessoal e particular do trabalhador, privando-o do convívio familiar e social, assim como do lazer.

No ordenamento jurídico brasileiro, a jornada comum de trabalho consiste em oito horas diárias e quarenta e quatro horas semanais (conforme o art. $\underline{70} \underline{\text { XIII, }}$ da $\underline{\text { CF }}$ e artigo $\underline{58}$ caput, da $\underline{\text { CLT)}}$ ), admitindo a prorrogação e compensação de jornada (art. $\underline{59}$ da CLT, e 7ํㅗ XIII, da CF) em número não excedente a duas horas diárias. Torna-se importante destacar, que o intervalo de quarenta e quatro horas semanais, assim como outros direitos sociais trabalhistas (férias remuneradas, licenças-maternidade e paternidade, descanso remunerado, dentre outros) foram conquistados a custos humanos, por meio de lutas e embates sangrentos, nos quais muitos trabalhadores e trabalhadoras perderam suas próprias vidas.

A jornada exaustiva inicia-se a partir de doze horas de labor, aplicando o artigo $61 \S 2^{\text {o }}$ da CLT. 0 artigo trata casos excepcionais em que a lei possibilita a extensão da jornada de trabalho para além das dez horas. Salvo a força maior que não possui limitação, excepcionado o menor, nenhuma jornada pode ultrapassar doze horas. Tal posicionamento encontra prestígio no âmbito do MPT.

\section{CONDIÇÕES DEGRADANTES}


Condições degradantes são o modo de execução que mais dá trabalho para a doutrina e para a jurisprudência. Melo (2003, p. 15), ao descrever condições degradantes, relaciona às péssimas condições de trabalho e indica situações em que verifica trabalho degradante, como: intermediação fraudulenta do trabalho; submissão a condições precárias pela falta ou inadequado fornecimento de alimentação e água potável; existência de alojamentos sem condições mínimas; não fornecimento de instrumentos para o trabalho e de proteção individual; não cumprimento da legislação que rege o trabalho humano, etc. 0 art. $1^{\circ}$. da Constituição Brasileira já garante a dignidade da pessoa humana (...) os valores sociais do trabalho e da livre iniciativa, (...) ninguém será submetido a tortura nem a tratamento desumano ou degradantes etc. $O$ desafio seria fazer cumprir a carta magna.

Condições degradantes seriam tratamentos aos trabalhadores que causam desumanização e assemelha a pessoa a coisas ou objetos (BRITO FILHO; CARDOSO; LITAIFF, 2017).

Segundo a OIT (2018), a condição análoga a de escravo com a presença de trabalhos forçados e condições degradantes afeta não só o cerceamento da liberdade, mas toda garantia à dignidade. As pessoas recorrem à constante fuga da pobreza e involuntariamente se submetem a condições desumanas, devido a deficiências ligadas às provisões de necessidades básicas, que são obrigações que deveriam ser suportadas pelo Estado. Quanto piores as condições de vida, mais os trabalhadores estarão dispostos a correrem os riscos de se sujeitarem a um trabalho que apresente situações e condições degradantes.

\section{RESTRIÇÃO DE LOCOMOÇÃO}

Segundo a redação do artigo 149 do Código Penal, restrição de locomoção é o cerceamento do uso de meio de transporte por parte do trabalhador, com fim de retê-lo no local de trabalho. A omissão de fornecimento de serviço de transporte também entraria como restrição (artigo 149, §1o, inciso I, do Código Penal). Além disso, a manutenção de vigilância ostensiva ou violenta no local de trabalho ou fato do agente ou empregador se apoderar de documentos ou objetos pessoais do trabalhador, com o objetivo de retê-lo no local de trabalho (artigo 149, §1o, inciso II, do Código Penal). 
Segundo o antigo MTE, a forma mais comum de restrição da locomoção é quando o trabalhador é induzido ou forçado a contrair dívidas com o empregador para impedi-lo de deixar o trabalho em razão desse débito. De acordo com o extinto MTE, contrações de dívidas geralmente ocorrem antes de o trabalho começar, quando o empregador financia débitos do trabalhador, seja com passagem, alimentação ou moradia, seja por adiantamento de parte do salário para garantia de condições de subsistência. Também pode ocorrer depois que a prestação de trabalho começa, quando obrigam o trabalhador a pagar por ferramentas utilizadas no trabalho, pelo vestuário, alojamento, alimentação ou outra necessidade.

A sociedade impõe como cerceamento de liberdade, conceitos que tiram do indivíduo o livre arbítrio do ir e vir físico (prisão) ou que objetifiquem o ser humano (escravização) ou até mesmo que estabeleçam doutrinas que impliquem no que pode ou não ser feito no corpo; o pertencimento ao outro em contrapartida a pertencer a si mesmo, poder dizer não ao que lhe viola a moral e provoca mal estar, correspondem as maiores implicações de relações de domínio da humanidade. Instituições ou indivíduos que provocam essa relação de cerceamento de liberdade do corpo podem prorrogar relações invasivas à individualidade, tendo manifestação escravocrata.

\section{VIDA DE MODELO}

No início da carreira, já na primeira etapa, na agência de modelos, as modelos são criteriosamente avaliadas de acordo com seu perfil: traços físicos, idade, altura, medidas, composição gestual e postural. Feito isso, é indicada a fazer um material, ou seja, um book fotográfico para que então possa dar início ao trabalho. 0 jargão nas agências é que "o mercado está repleto de meninas lindas e de todos os tipos". Por isso, é preciso se diferenciar com outros atributos além do corpo, como a personalidade. É exigido que saiba como agir diante dos produtores, agenciadores e clientes (MARTINEZ, 2009).

Uma modelo é considerada pelos agentes como vendedora e embalagem. Cabe a ela se vender como um produto que seja lembrado e escolhido. Para isso, deve ter um rótulo que as diferencie das demais, que chame a atenção no mercado. Isso inclui as atividades cotidianas, 
atitudes, modos de se vestir, de se portar e de sentir. Ela deve se tornar uma marca, criando uma personagem para si que comunique um diferencial. A todo o tempo, tem seu corpo analisado através dos castings, que são seleções anteriores aos trabalhos (MARTINEZ, 2009).

A escolha pela magreza não é consciente, mas a opção resultante da pressão sociocultural, à qual não se vislumbra outra saída. Quando não adotam padrões, são excluídas das agências e imediatamente substituídas (VAL; CARVALHO; CAMPOS, 2015).

A idade média de uma menina que ingressa na vida de modelo é de 14 a 17 anos. Muitas vezes, agências já mantêm contato com famílias de meninas que não completaram seus 12 anos, indicando que as levem para agências locais infantis para se familiarizar com o mercado através de pequenos trabalhos. Muitas chegam a São Paulo sem terminarem o ensino fundamental ou médio. Outras, sem o acompanhamento dos pais. Passam a morar no apartamento das agências com cerca de 6 a 10 outras modelos (MARTINEZ, 2009).

Ainda segundo Martinez, são influenciadas a levar a carreira a sério, como única atividade. Porém, os trabalhos são esporádicos. Além disso, grande parte não tem retorno financeiro, e quando tem, o dinheiro é encaminhado à agência por conta da dívida criada com adiantamentos de condução, alimentação, moradia e material fotográfico. Tudo isso é de incumbência da modelo. Em contrapartida, a agência se coloca como responsável dessas jovens meninas, mantendo-as reclusas e sob vigilância constante.

Para Martinez (2009) há disciplinarização e lapidação ao ensiná-las que são um "produto" que deve saber o que falar e como se comportar, sempre lidando com a rejeição e críticas a respeito de suas próprias imagens. São consideradas seres moldáveis, uma vez que ensinam como se posicionar no mundo, por vezes, diferente de como aprenderam até então.

\section{PRESSÕES SOCIAIS DO GÊNERO FEMININO}

O padrão estético para o corpo da mulher é visto como violência psicológica (VIANNA, 2005). As características impostas pela sociedade, como corpos magros, aparência jovem e traços europeizados não são características compatíveis com a maioria das mulheres. Pelo 
contrário, muitos desses corpos violam noções científicas de um corpo saudável. Pela falta de aceitação do próprio corpo, muitas adquirem distúrbios alimentares, dificuldades de se inserir social e profissionalmente. Tais pressões são impostas desde a infância.

Ainda segundo Vianna (2005), a imagem que a mídia passa sobre o corpo feminino é irreal, discrimina parte das mulheres, influencia negativamente a aceitação da diversidade, adoece jovens que ainda estão em fase de desenvolvimento físico e mental.

A tentativa de atingir padrões causa autocontrole, sofrimento, ansiedade, insatisfação com a aparência e forma corporal, depressões, distúrbios alimentares, fobias, crises de pânico e comportamentos aditivos (FIGUEIRERO, NASCIMENTO e RODRIGUES, 2016).

A sociedade contemporânea, segundo Figueiredo, Nascimento e Rodrigues (2016) é individualizada e mercantilista. Os indivíduos se preocupam cada vez mais com a aparência, performance e estética. 0 discurso do culto ao corpo nos distancia de questões graves, como desigualdade social, miséria, altas taxas de desemprego, hierarquia de classe, gênero e raça, fragilização de relações trabalhistas, intensa competitividade, falência do modelo de produção capitalista neoliberal, destruição do meio ambiente e baixa qualidade de vida.

Mulheres são ensinadas, através de identidades femininas em circulação, sobre modelos corporais, estilos de vida e identidades. Sofrem pressões para ter o corpo padronizado e estado psicológico almejável pelos espectadores: feliz e bem sucedida

\section{METODOLOGIA}

A pesquisa qualitativa é relevante no estudo de relações sociais por conta da pluralização das esferas da vida. As mudanças sociais e consequentemente, diversificação dessas esferas, resultam em enfrentamentos de novos contextos, situações e perspectivas por parte dos pesquisadores (FLICK, 2009).

Neste artigo, os dados foram coletados a partir de entrevistas semiestruturadas. A análise do material foi feita a partir das diretrizes de Saldanã (2013). A escolha por realizar entrevistas semiestruturadas foi feita devido a oportunidade de obter informações sobre o 
pensamento das entrevistadas, a partir de questões emergentes do referencial teórico (BRYMAN, 2008).

Segundo Manzini (2004), a entrevista semiestruturada permite questionamentos que se relacionam com o tema para atingir o objetivo pretendido da pesquisa. A partir disso, outras questões podem surgir de acordo com a circunstância. Esse tipo de entrevista pode fazer emergir informações de maneira mais livre e as respostas não são condicionadas a um padrão.

Participaram desta pesquisa cinco modelos profissionais, brasileiras, com mais de três anos de carreira e que já tinham tido experiência tanto no mercado brasileiro quanto no exterior.

Para isso, o contato com as componentes foi feito por meio da técnica snowball, em que um entrevistado da pesquisa indica outros possíveis participantes para as próximas entrevistas até que se encontre o "ponto de saturação", entendido como o momento em que as respostas começam a ser repetitivas, sem adicionar informações novas relevantes para a pesquisa (BALDIN \& MUNHOZ, 2011). Essa técnica foi combinada com a própria rede de contatos de um dos autores desse artigo, que trabalha no ramo há 11 anos.

Ainda de acordo com Manzini (2004), a coleta de dados pode ser pessoalmente ou mediada por telefone e internet. Como algumas modelos moram em outras cidades ou país, três das cinco entrevistas foram feitas por ligação telefônica/facetime e as outras face a face.

Garantir que identidade dos participantes fosse preservada na pesquisa representou uma questão fundamental. Diante dos cuidados éticos, diálogos e identificação de possíveis desconfortos, neste trabalho, houve a preservação da identidade das entrevistadas, utilizando nomes fictícios. Todas assinaram um termo de cessão gratuita de direitos de depoimento oral e compromisso ético de não identificação do depoente. Foram seguidas rigorosamente as normas e diretrizes dispostas na Resolução CNS 466/12.

No quadro a seguir, as participantes são apresentadas com nomes fictícios, idade, tempo de carreira como modelo, estado civil e cidade.

Quadro 2 - Perfil das entrevistadas 


$\begin{array}{lllll}\text { Nome } & \text { Idade } & \text { Tempo de carreira } & \text { Estado Civil } & \text { Cidade } \\ \text { Thais } & 22 \text { anos } & 5 \text { anos } & \text { Solteira } & \text { Chapecó } \\ \text { Louise } & 25 \text { anos } & 10 \text { anos } & \text { Divorciada } & \text { Rio de Janeiro } \\ \text { Sofia } & 26 \text { anos } & 7 \text { anos } & \text { Casada } & \text { Rio de Janeiro } \\ \text { Alice } & 21 \text { anos } & 6 \text { anos } & & \text { Niterói } \\ & & & \text { Solteira } & \\ \text { Luana } & 26 \text { anos } & 12 \text { anos } & \text { Solteira } & \text { Niterói }\end{array}$

Fonte: Elaborado pelos autores (2020).

Destaca-se que um dos autores desse artigo atua como modelo profissional há 11 anos, o que lhe possibilitou conhecer empiricamente a realidade desse tipo de trabalho. 0 estudo foi configurado pelas exigências acadêmicas de um TCC-Trabalho de Conclusão de Curso de ensino de graduação em Administração de uma universidade federal.

Vale ressaltar que todas as entrevistadas já tiveram experiência internacional. As participantes possuíam em média 24 anos de idade, sendo a mais jovem com 21 anos e a mais velha com 26 anos. 0 tempo médio como modelo era de 8 anos, sendo duas delas com mais de 10 anos na profissão e três trabalhando no máximo há 7 anos. Uma delas iniciou a carreira aos 14 anos.

As entrevistas tiveram os áudios gravados para posterior análise e uma média de duração de dezessete minutos.

Após a coleta de dados, os registros do conteúdo foram utilizados para análise, com suporte do referencial teórico. 
Os métodos de codificação e análise dos dados foram baseados em Saldaña (2013), que elaborou um manual de codificação para pesquisas qualitativas. Para o autor, durante a análise de dados qualitativos, os códigos são unidades de sentido, elaboradas pelo pesquisador, que simbolizam e atribuem interpretação às unidades separadas de dados.

0 detalhamento, qualidade e flexibilidade do método fazem com que seja o mais adequado para pesquisa, pois o processo tem o propósito de detectar padrões, analisar, categorizar os dados a partir de categorias prexistentes ou não, contribuindo para observações teóricas.

O processo tem início com a leitura ou observação preliminar dos dados, com a marcação e grifos de trechos que chamem a atenção do pesquisador. A codificação permite que os dados sejam divididos em partes menores, em que se atribui sentido para identificação de padrões. Esses códigos, por sua vez, podem ser agrupados em categorias, que em sua análise formarão temas e conceitos. Por fim, os resultados são interpretados à luz do referencial teórico, em que os temas e conceitos formam contribuições para o desenvolvimento da teoria, a partir da observação dos padrões e de como esses temas se inter-relacionam (Saldaña, 2013).

Nesta pesquisa, foram estabeleciadas categorias a priori, baseadas no referencial teórico construído. Tais categorias também foram utilizadas na elaboração do roteiro de entrevista. Durante a interpretação dos dados, os temas foram analisados de acordo com as categorias estabelecidas anteriormente, que se mantiveram durante a observação dos temas e padrões.

\section{REVELAÇÕES DO CAMPO}

A partir das entrevistas, foi possível compreender o processo de entrar para agência, como se dão os pagamentos, alojamentos, tempo de trabalho, visão da mão de obra e etc.

\section{JORNADA EXAUSTIVA}

0 pilar de Jornada Exaustiva como categoria de analogia à escravidão contemporânea, discutida anteriormente, pôde ser identificado em algumas falas. 
Segundo Alice, existem as meias diárias e diárias inteiras, mas na maioria das vezes o trabalho tem duração de uma diária inteira, que correspondem a oito horas.

Mas é só uma teoria, né... que nunca termina no prazo certo. (ALICE)

Ela conta de um caso em que o trabalho iria até às 17 horas, mas durou até às 20h:30, e não recebeu as horas extras que lhe foram prometidas. Nesse mesmo trabalho, a cliente se referiu a ela como "espantalho" e "cara de peixe morto". Observa-se o uso de constrangimento físico e moral, citados por Barboza (2011).

Thais conta que o normal seriam oito horas de trabalho, mas já trabalhou das $7 \mathrm{~h}$ até às 20h sem receber hora extra. Segundo ela, o Brasil até respeita mais a questão de hora extra.

Quando eu fiquei na China, por exemplo, eu tinha trabalhos que eram $12 \mathrm{~h}$ de trabalho e eu tinha 30 minutos de intervalo. Inclusive, quando eu fui, pagavam por hora... quando eu queria ir no banheiro, alguém me acompanhava para ver se eu ia no banheiro mesmo ou se eu ia perder o tempo que eles estavam me pagando, no telefone. (LUANA)

Luana conta que depois de alguns anos de experiência, passou a não aceitar mais essa situação com facilidade e fragilidade.

Mas mais novinha eu aceitava tudo... eu tinha um pavor, porque quando eu comecei a modelar eu aprendi muito a frase "entra muda e sai calada". Então eu entrava no trabalho assim... eu tinha medo de falar até que eu estava com fome... eu achava que eu não podia sentir fome... e eu também sempre fui muito neurótica com questão de magreza, hoje em dia não... então na época eu pensava: primeiro que eu nunca estava magra o suficiente, segundo que, se eu achava que não estava magra o suficiente, imagina se eu falasse que estava com fome, né... o que iriam falar de mim? (LUANA)

A mesma entrevistada contou sobre um trabalho que fez, a modelo ficou com vergonha de falar que estava com fome e desmaiou no final do trabalho.

Louise explica que atualmente não faz mais do que 8 horas sem ganhar hora extra, mas que já fez muitas vezes na vida 
Eu já devo ter trabalho muitas vezes 12, 15 horas... normal assim... super normal! (LOUISE)

Sofia explica que alguns clientes pagam hora extra e outros não:

Inclusive esse negócio de dinheiro é muito bizarro, porque você não pode contar com o seu dinheiro mensalmente. Você não pode fazer uma compra, esperando que vai receber. Tem que pagar tudo à vista, porque você não sabe quando realmente vai receber, sabe? (SOFIA)

Diante das respostas, é possível observar a presença da jornada exaustiva, que de acordo com artigo da CLT, inicia-se a partir de 12 horas de labor. Conforme Marinho e Vieira (2019), a jornada exaustiva acontece tanto no que se refere à extensividade ou intervalo de carga horária, quanto no que tange à intensividade. Quando Luana conta que fez trabalhos por 12 horas, tinha 30 minutos de intervalo e a acompanhavam ao banheiro, percebe-se que além de trabalhar por muitas horas, tinha que ser extremamente produtiva com pouco descanso. Por outro lado, cumpre relativizar os parâmetros de extensividade e intensividade, presentes nesse tipo potencial de exaustão, na medida em que o respectivo pagamento de horas extras não poderia eximir a organização do trabalho de modelo de um paralelo com preceitos da escravidão. Em outras palavras, o princípio básico norteador da dignidade da vida humana e de decência do trabalho, defendidos em orientações normativas da OIT Organização Internacional do Trabalho e da própria Constituição Federal Brasileira acabam sendo negligenciados.

\section{CONDIÇÕES DEGRADANTES?}

Alice contou que no último casting, pediram-lhe pra que ela perdesse dois centímetros de quadril para que fizesse o desfile. Já Thais conta que em um casting a modelo vai para que o cliente a veja, e nem sempre são gentis. Ela recorda sobre uma fila de casting para desfile: 
Um frio horrível, aquele frio que você nem consegue ficar parada na fila, aí você chega para desfilar para o cliente, ele mal olha para sua cara. Você mal entra e ele já te manda embora (...) Às vezes você está em uma fila de modelos, colocadas que nem cabide na frente do cliente, para eles dizerem "está bom, obrigado!" e nem olharem para a sua cara, e te mandarem embora na frente de todo mundo. (THAIS)

Para Luana, em um casting, a modelo vai ao cliente para que ele a veja, faça perguntas, analise suas fotos e, às vezes, tirarem suas medidas. Conta que hoje em dia os clientes perguntam quantos seguidores possuem e relembra que quando foi para Londres fazer seleção, a primeira pergunta foi qual o Instagram dela e quantos seguidores possuia.

Louise diz que a agência entra em contato com as informações sobre o casting (data, horário, local) e então a modelo vai.

É uma entrevista de emprego, para conhecer o cliente. Eu chego, o fotógrafo me olha, vê minha aparência, conversa um pouco, faz algumas perguntas, às vezes tira fotos, ou só olha as fotos do book. Isso dura menos de cinco minutos. (LOUISE)

Ela completa falando sobre o tempo de espera para fazer um casting e relata que já esperou por 8 horas, todo tempo sem alimentação e lugar para se sentar. Por vezes, dão água.

Um casting, a princípio é apavorante, porque você tem que entender que você tem que estar muito bonita, muito bem arrumada. Aí você chega e tem milhares de pessoas muito idênticas a você e então pensa "meu Deus, eu não vou pegar isso aqui nunca, porque todo mundo é igual a mim só que mais bonita" e então o cliente olha pra você muito rápido, mal dá um oi e vai embora. Acabou. Casting é assim. Muito rápido e muito nervoso. A espera é longa. Antes da gente ver o cliente, a gente fica em uma sala, normalmente, com todas as modelos iguais a você... eu já esperei por 6 horas, porque eram 400 pessoas...(SOFIA)

Essas informações corroboram com o que Barboza (2011) defende como condições de trabalho degradantes, em que o trabalhador é submetido a constrangimento físico e moral. Para Melo (2003), também há indícios quando não existe fornecimento de alimentação e não cumprem a legislação que rege o trabalho humano. 
Além disso, se relacionam com o que Bauman (2007) diz sobre a sociedade ser estimulada e forçada a cumprir com quesitos impostos pelo mercado, seguindo uma vida que gera insegurança, estresse e comparações intermináveis.

A quinta pergunta foi referente a como funciona o pagamento à modelo.

Então... o certo seria que nós recebêssemos após trinta dias. Nem sempre acontece, ou quase nunca... eu já fiquei até três meses com o meu cachê atrasado. A gente não tem nem o direito de reclamar, porque quando a gente tenta falar alguma coisa com a nossa agência, eles falam que a culpa é do cliente... que tem que esperar. Como se a gente não tivesse contas para pagar. (ALICE)

0 ideal seria que após trinta dias você recebesse. Mas nem sempre é assim. Tem vezes que demora dois meses, três meses, e aí vai. Dependendo da agência, não paga. Você fica esperando, esperando, demora, e você tem que ficar meio que implorando pra agência pagar. Mas... é isso! (THAIS)

Luana explicou que a dívida que citou refere-se ao adiantamento que a agência faz para a modelo, comprando sua passagem, dando um valor para viver semanalmente e para aluguel. Além disso, cobram para colocar fotos das modelos no website. A partir do momento que a modelo começa a trabalhar, a dívida vai sendo descontada até ser quitada. 0 pagamento só é feito após o saldo ficar positivo e o contrato terminar. Porém, conta de um caso de quando estava na China e conseguiu chegar ao saldo positivo, mas nunca recebeu. Ela finaliza dizendo que foi embora sem reclamar, por medo e insegurança.

$\mathrm{Na}$ época eu tinha dezessete anos e eu era ainda muito bobinha... e no papel dos cachês, do dinheiro que tinha entrado e que saía, eles fizeram de uma forma que não sobrava dinheiro nenhum. Eu já tive vários cachês que eu trabalhei e que eu não recebi. A agência nem corre atrás pra cobrar e colocar na justiça... eu que me ferro. A gente que vai lá, trabalha, fica o dia inteiro lá e se ferra. Geralmente, o certo seria pagar em um mês, mas as coisas não acontecem assim... a maioria das modelos recebe através do intermediário que é a agência. Então o cliente paga à agência, que paga à modelo. E aí demora mais ainda, porque se a agência enrola, demora mais ainda a pagar a modelo. (LOUISE) 
O certo seria assim... trinta dias após o trabalho. Mas normalmente não acontece isso. Muitos clientes enrolam. Já teve cliente que demorou quatro meses para me pagar... a gente espera... se o cliente não paga a gente fica cobrando, cobrando, cobrando à agência, aí a agência fica cobrando ao cliente, mas eles pagam quando querem. 0 certo é isso: deu trinta dias, ninguém cobrar e estar na minha conta, mas muitas vezes atrasa. Muitas. (SOFIA)

As experiências das entrevistadas, quanto ao pagamento, fazem relação ao discurso de Figueira (2000) sobre o que as vítimas da escravidão contemporânea sofrem com o desconhecimento da lei, com a inocência e ignorância. Vilela (2000) argumenta que a maioria dessas pessoas apresenta ingenuidade e pureza.

Alice conta que um dos principais fatores de ter voltado de suas viagens antes do previsto foi o alojamento. Quando estava com 18 anos foi para São Paulo e relata:

Eu cheguei lá, na casa... era uma casa com catorze meninas, tinham dois quartos e em cada quarto tinham umas camas de beliche. Não tinha armário. Só tinha cama... nossas roupas ficavam na mala e eu ia ficar três meses lá... A geladeira só tinha uma para catorze meninas... se você compra uma abóbora, acabou com a sua prateleira. Só tinha um banheiro... enfim, era um caos... E a gente paga... os alojamentos não são de graça. (ALICE)

Em seguida fala sobre sua experiência em Londres. Conta que assim que chegou, colocaram-na em um bom apartamento, com condições normais. Depois de três dias, trocaram-nas de alojamento. Ela e outra modelo que havia chegado ao mesmo tempo.

Era um prédio muito estranho, no meio do nada... e uma escadaria, onde a gente teria que ficar no nono andar. Então imagina que a gente ia ter que subir nove andares com as malas... Quando entramos, a casa estava totalmente suja, tinha uma menina trancada no banheiro... usando droga... quando abrimos a porta do nosso quarto tinha um varal de chão, com as calcinhas sujas das meninas que já moravam lá... Não tinha colchão, só tinha uma cama... nós tivemos que pegar o colchão de um outro quarto e arrastamos pelo chão... enfim, eu voltei para o Brasil por causa dos problemas que eu tive nesse apartamento. Não tinha como ficar lá. Era podre... Eu nunca fui em um lugar 
tão sujo... A agência não me deu outra opção de moradia. Ou eu ficava lá... ou eu ficava pagando um hotel. (ALICE)

Ela finaliza contando que, além de tudo, o aluguel do alojamento era caro. A agência não deu opção de mudança e não tomou providencias com quem causou a situação.

Thais conta que suas experiências foram relativamente boas e teve a oportunidade de morar com meninas que vieram a se tornar grandes amigas. Apesar de já ter tido problemas, acredita que as coisas boas foram mais fortes do que as ruins.

Uma vez em Milão... o apartamento era muito pequeno, e tinham acho que oito pessoas e era tudo em beliche... a gente não tinha um espaço adequado. Não tinha nem armário direito... e eu lembro que o valor do aluguel era absurdo... Mas o que superou foi na Turquia. 0 apartamento era grande... tinha nosso espaço... mas eles enfiavam, no mínimo, dez modelos, para dois banheiros, e cada uma tinha que pagar por mês quinhentos dólares, sendo que não era isso tudo... ai eu só morei por dois meses e depois procurei outro lugar. (LUANA)

De verdade... são sempre umas casas horríveis. Umas casas que não tem estrutura, eles amontoam um monte de menina e cobram caríssimo. Eles superfaturam a casa sempre, porque muitas vezes a casa é da própria agência... ou até alugam, mas aí eles ganham dinheiro em cima. A agência ganha dinheiro em cima do valor que realmente aquela casa custaria. (LOUISE)

Em São Paulo foi horrível, porque eram treze meninas em uma casa muito pequena, com dois quartos só... era bagunçado e só tinham duas geladeiras para dividir com essas treze meninas... Comida cada uma comprava a sua... (SOFIA)

No meu caso, eu voltei antes. Então nós temos que arcar com as dívidas que ficam com a agência... de apartamento, passagem aérea, que geralmente eles antecipam pra gente... A maioria das agências tem uma multa... tem agência que eu conheço que tem multa de vinte mil se você romper o contrato... eu dei sorte que eu não tive essa multa... mas os trabalhos que eu fiz ficaram para a agência, como parte da minha dívida... eu voltei e não recebi nada. (ALICE) 
Thais responde que o contrato das viagens é de cerca de três meses e nesse tempo ficam vinculadas à agência. Se a modelo quiser, por vontade própria, quebrar o contrato e voltar antes do tempo, pode ter problemas com a agência para conseguir retornar.

Luana conta que nesse vínculo algumas regras devem ser cumpridas, como não chegar no apartamento mais tarde do que permitem.

Na Turquia, por exemplo... no apartamento você não podia chegar depois das dez da noite... se você não obedece... a agência tirava ou o seu pocket money, ou falava com a sua agência mãe. (LUANA)

Pocket Money é o dinheiro emprestado semanalmente para alimentação e transporte.

É louco né... sempre quando a gente vem viajar, eles meio que falam assim "ah, ela vai vir por três meses", porque é realmente complicado quebrar esse contrato... porque a gente vem com as coisas meio que adiantadas... adiantadas que no caso a gente trabalha e paga... então no final é do nosso bolso. Mas aí eles se sentem no direito de você ser obrigada a ficar em um lugar, porque eles adiantaram aquilo... obrigada a estar naquele lugar por aquele período... (LOUISE)

Ela segue explicando que dependendo da agência mãe (do país de origem) que a menina tiver, pode ser ajudada. Se estiver há meses e o saldo não for positivo, a agência mãe negocia um outro lugar ou a volta para casa. Mas em muitos casos há obrigação de ficar.

O que muda muito nessa profissão, que eu vejo, eu que comecei novinha, é a maneira como você se porta. Como eles lidam com uma menina de quinze e como uma menina de quinze não fala e ficaria... e como uma pessoa mais madura não aguenta qualquer coisa... A maturidade é o que ajuda a você ter mais voz nessa profissão... você vai vendo que não precisa ficar calada em tudo, não precisa aguentar tudo calada, você não precisa ficar obrigada em um lugar. (LOUISE)

Sofia se assemelha às demais sobre o tempo de permanência ser de três meses e sobre a agência costumar adiantar a passagem, a hospedagem e o pocket money. 
Antes de três meses se você quiser voltar e não tiver pago a dívida, eles vão querer te prender lá... eles não vão querer simplesmente que você vá embora. Eles vão fazer de tudo para que você fique lá para pagar suas dívidas... (SOFIA)

Conta que se a modelo quiser ir embora, deve arcar com custos da passagem e do restante da dívida.

Diante dos relatos, podemos fazer relação com outra conduta do trabalho escravo contemporâneo: restrição de locomoção. Segundo o extinto MTE, as dívidas costumam acontecer antes mesmo do trabalho começar, como é o caso das modelos que vão viajar contraindo dívidas de passagem, hospedagem e o dinheiro semanal. Dessa maneira, ficam à espera de trabalho enquanto contraem dívidas.

Existe um contrato em que assinam antes de viajarem. Mas assinam em busca de um sonho que é vendido, com promessas de sucesso. Quando chegam ao destino, vão contraindo dívidas e só podem ir embora caso paguem o que devem.

A nona pergunta foi referente a forma como enxergam a mão de obra de uma modelo. O objetivo dessa questão foi entender a visão pessoal de cada uma sobre a carreira.

Eu vejo como um produto descartável, tipo um copo de plástico que você bebe água e joga fora, porque como tem muita oferta... não só de ter muitas modelos boas e bonitas. Tem muitas modelos que aceitam trabalhar de graça, que aceitam trabalhar por qualquer migalha que ofereçam. Isso acaba desvalorizando nós, que somos modelos, que precisamos trabalhar, precisamos de dinheiro, que a gente leva a profissão a sério para pagar nossas contas... (ALICE)

Alice diz que por existir muita oferta, a modelo acaba por não reclamar, caso se sinta insatisfeita. Segundo ela, iriam julgar mal e limitar os trabalhos.

E no nosso meio a gente não pode ficar se queimando, né? Porque as coisas espalham muito rápido. (ALICE) 
A resposta com Bales (2011), quando afirma que a mão de obra da escravidão contemporânea é descartável devido ao grande contingente de trabalhadores desempregados.

Segundo Thais,

a modelo é um molde. Então quando você não está de acordo com o que a agência busca, você se torna descartável. (THAIS)

Ela fala que é uma profissão incerta, pois não existe um salário mensal. Compara a carreira a vínculos de trabalho tradicionais, em que acredita que se tem mais estabilidade.

A gente depende da sorte, de estar no lugar certo, das pessoas gostarem de você, e ainda, das exigências do mercado". Ela finaliza dizendo que para uma menina ingressar na carreira de modelo, tem que gostar muito. "Você vai levar muitas críticas, vai levar muitos nãos, as pessoas, normalmente, não são tão gentis com você... você tem que saber que vai estar exposta às incertezas... (THAIS)

Quando comecei tinha muita questão de ser apenas um padrão, não valorizam uma modelo como deveria ser valorizada... Tem uma questão também.... Não preparam uma modelo para ser modelo... ninguém tem o psicológico pronto para isso. Você sofre muita pressão. Se você começa nova... você acaba acreditando em tudo o que te falam, acaba acreditando que só existe uma verdade, um padrão a se seguir. Se você não for aquele padrão, não pode continuar sendo modelo... (LUANA)

Luana diz que nunca se sentia boa o suficiente, pois a fizeram acreditar nisso. Conta que por mais que estivesse nas medidas estabelecidas, sempre alguém pedia que emagrecesse, gerando pressão. Ela fala que já passou por situações que a agência repreendia seu corpo, criticando ou comentando que se não emagrecesse, não teria trabalhos. $\mathrm{E}$ questiona:

Até que ponto o mundo da moda te trata da forma que é para você ser tratada? Eu novinha falavam para mim "você tem uma semana para emagrecer". Tá. O que que eu 
faço? "Para de comer. Bebe só água... Come só alface... que você emagrece". E eu realmente tentava comer só alface. Eu já fiz cada loucura... (LUANA)

Muitos lugares, muitas marcas e muitas pessoas veem a mão de obra de uma modelo, sei lá, como um cabide mesmo... como se não sentisse nada, não sentisse fome... Eu sinto não valorizada, muitas vezes. (LOUISE)

Em alguns casos, o trabalho é pago com permuta... ao invés de te dar o dinheiro, eles te dão roupa. (SOFIA)

Segundo Sofia, muitos trabalhos não dão alimentação. Hoje, conta que não admite mais essas situações, mas no início da carreira não queria se expor ou recusar trabalhos.

Uma vez estava em um trabalho e eu desmaiei, porque não tinha comida. (SOFIA)

Ela lembra de outra vez em que a cliente parou para almoçar, comeu, não quis a salada e então ofereceu a ela. Nesta ocasião e em algumas outras, diz não ter se manisfestado por medo. Sofia também recorda outra situação em que estava em um trabalho sem comer durante muitas horas e então a cliente comprou um salgado para três modelos dividirem.

É possível observar, nas respostas, condições degradantes (BRITO FILHO; CARDOSO; LITAIFF, 2017), o tratamento aos trabalhadores, quando há desumanização.

A décima pergunta foi sobre ameaça e/ou violência psicológica.

Então, isso eu acho que a gente sofre diariamente... é muito difícil a gente ir em um casting ou na agência e nunca falem nada de ruim da gente... que a gente precisa emagrecer, ou cortar o cabelo, ou que está muito acima do peso... A gente recebe críticas diárias, e eu acho que o nosso psicológico fica abalado sempre. (ALICE)

Segundo Alice, a modelo deve se moldar ao que a agência pede. Não há poder de escolha sobre o próprio corpo ou aparência. Ela diz que nunca consegue ser quem quer ser.

No momento eu estou com o cabelo curto, mas eu queria ter o cabelo grande, mas aí a minha agência não me permite". Da última vez que ela estava com o cabelo grande, 
perguntaram se tinha feito alguma promessa, se eu tinha entrado em alguma igreja... que meu cabelo dava para eu sentar e fazer balanço. Que desse jeito não ia ter como trabalhar. Nenhum cliente ia querer. (ALICE)

As agências têm essa tendência de querer mudar a modelo. De deixar a menina estranha, de querer mudar a personalidade dela, "se veste dessa forma, faz isso, faz aquilo", e você vai perdendo um pouco da sua personalidade... (THAIS)

Thais diz que quando a modelo aprende a lidar com a pressão e a lidar com "nãos", aprende também a entender quem é.

Quando você não entende e tentam te mudar o tempo todo, é muito difícil você lidar com essa situação. Tiveram umas três vezes que eu fui conversar na agência e eu saí destruída, chorando, desesperada porque parecia que eu estava em um círculo que eu não conseguia sair... No fundo eu sabia que eu não precisava daquela agência, e eu não precisava daquela mulher falando aquilo para mim. Mas eu, ao mesmo tempo, não tinha forças de sair... Tiveram dias que eu não queria sair de casa... (LUANA)

Luana contou que modelou por 12 anos até perceber que o que amava não a fazia feliz. Foi quando decidiu dar uma pausa e iniciar tratamento com terapia. Hoje se sente saudável.

A gente trabalha com a nossa imagem, mas eles não falam muito sobre se amar, ter amor próprio, amar seu corpo como ele é. Eles querem que a gente ame o nosso corpo como eles querem que seja. E aí você acaba acreditando nisso fielmente e acaba ficando cega para o que você é de verdade. (LUANA)

Para finalizar, diz que tem começado a ver uma mudança no mercado. E esse ano começou a ver corpos diferentes aparecerem. E espera que isso continue, para que meninas não venham a ter doenças psicológicas. Louise fala das exigências e do mercado:

O mercado pede que elas tenham oitenta e nove / noventa centímetros de quadril, mas eu sou brasileira, brasileira tem curva. Realmente é uma profissão que só vão olhar a carcaça, sabe? Nunca está bom, nada. 0 cabelo está ruim, o corpo está ruim, o quadril está grande... muita pressão, sabe? É muita pressão psicológica. Você imagina 
isso na cabeça de uma adolescente... Se eu com vinte e cinco anos sofro, choro, muitas vezes... dez anos atrás, nossa! Eu sofria muito... Quando eu ouvi a primeira vez "você precisa emagrecer"... aí começou toda a pressão psicológica, que na verdade o meu corpo não suporta. (LOUISE)

As questões sobre corpo fazem relação com Vianna (2005), quando fala que o padrão estético para o corpo de uma mulher é uma violência psicológica. Ocorre uma violação do que seria um corpo saudável, a partir de distúrbios alimentares.

Sofia, que é negra, conta das suas experiências com o racismo:

É bizarro como o racismo está entranhado na sociedade. É nítido para mim, que vivo isso. Na moda é pior ainda. Então eu sempre tinha que estar mais bem vestida, eu tinha que estar com o meu cabelo melhor, liso... agora até que aceitaram o meu cabelo natural... mas no começo era liso. Já me falaram que tinha me cuidar, pois era a única negra no mercado. (SOFIA)

Ela conta que certa vez, para um casting de desfile na semana de moda de São Paulo, a agência falou que não iria apresenta-la para um cliente que não aceitava negras. Em outro episódio, estava com um coque no cabelo e disseram estava parecendo um abacaxi.

Em relação à magreza, Sofia nunca teve problemas. Sempre teve naturalmente o corpo exigido, mas conta que morou com meninas e viu muitas delas diariamente comendo apenas alface, fazendo suco de pimenta para emagrecer, outras só fumavam.

Eu vendo uma menina de dezesseis anos, fumando para emagrecer, achei um absurdo. Mas o booker falava: melhor assim do que comendo. (SOFIA)

Podemos relacionar a condições degradante através da desumanização, transformando pessoas em bens (BRITO FILHO; CARDOSO; LITAIFF, 2017). Em que o objetivo é apenas o lucro. Para Bauman (2007), as pessoas têm que se moldar para que consigam chamar atenção e se manterem em uma boa posição nas "prateleiras".

\section{CONSIDERAÇÕES FINAIS}


Esse estudo teve como objetivo dar voz à mulheres modelos, que têm pouco lugar de fala. 0 intuito foi entender o backstage, o que está por trás do que a mídia passa sobre como é a vida profissional de uma modelo. A partir do levantamento bibliográfico e da realização de pesquisa de campo, foi possível relacionar a escravidão contemporânea à carreira de modelo.

Apesar de pontos positivos que a carreira traz, conclui-se que esse modelo de trabalho aponta sinais de escravidão contemporânea em três das quatro condutas específicas, segundo o artigo 149 do Código Penal. São elas: condições degradantes de trabalho, jornada exaustiva e restrição da locomoção; deixando de lado apenas o âmbito de trabalho forçado.

Em última análise, há condições degradantes pelo relato das muitas horas de castings sem comida, pela desumanização, ao assemelhar a modelo a uma mercadoria, nas críticas ofensivas, violências psicológicas e também por condições dos apartamentos que, segundo elas, não tem estrutura para receber muitas meninas.

Um produto descartável, tipo um copo de plástico que voce bebe água e joga fora... (ALICE)

A jornada exaustiva fica explícita a partir dos relatos de longas horas de trabalho, muitas vezes sem receber horas extras e com pouco tempo de descanso.

A restrição de locomoção é identificada perante os relatos sobre tempo de estadia em uma experiência de viagem, em referência aos adiantamentos que as agências costumam fazer como passagem, hospedagem e o pocket money, como conta Louise:

Eles se sentem no direito de você ser obrigada a ficar em um lugar porque eles adiantaram aquilo... (LOUISE)

Apesar de serem observadas essas três vertentes da escravidão contemporânea, observa-se que os balizadores das condições degradantes se encontram de maneira mais intensa, aparecendo em diversas respostas.

Foi observado que carreira tem início cedo e com meninas ainda em formação. Com isso, notou-se que, muitas delas, falam sobre o medo. Demonstram que quando começaram suas carreiras, tinham medo de reclamar do que as incomodavam, mesmo que achassem que 
não estava correto. Preferiam constantemente se calar para que não fossem mal vistas. Se submeteram a fome; demora no pagamento ou até a falta dele; demoras em castings; pressões recorrentes pelo corpo ideal; críticas ofensivas; negações; racismo.

Além disso, podemos fazer uma correlação com a ramificação psicológica do trabalho de modelo. As necessidades para se manter no meio profissional do estudo em questão se estendem além de uma prontidão para o serviço em si. Uma modelo não acaba por "despir" sua aparência quando se desloca do ambiente de trabalho e ela não é permitida que o faça, já que para manter todos os critérios pré-estabelecidos, não só estéticos como também sociais, como exemplificado pelo texto de Virginie Despentes, uma disciplina rígida acaba por ser necessária. A modelo acaba tendo que se preocupar com dieta a todo o tempo.

A vivência sobre um reflexo padronizado e crítico a nuances inerentes às diferenças pessoais, acaba por escravizar a profissional não só pela condição legislativa, mas também pelo psicológico. 0 "trabalho" é contínuo e provoca um sentimento de compromisso eterno, que conduz sua vida.

O estudo de campo teve abordagem qualitativa, com um número reduzido de entrevistadas e um tempo médio de entrevistas relativamente curto, mas que entendemos que cumpre seu papel para um debate introdutório no tema. Sugere-se que, em estudos futuros, busque-se conhecer percepções a partir de mais modelos; e que se amplie outras discussões direta e indiretamente correlacionadas aos achados desse estudo, tais como implicações desse tipo de trabalho no mundo da moda e questões de gênero. Além disso, sugere-se que a pesquisa seja realizada com agenciadores, para que se possa estudar a visão de quem está do outro lado da carreira de modelo. Este trabalho pretende deixar um legado para que outros pesquisadores tratem do tema em questão.

\section{REFERÊNCIAS}

ANTERO, S. Monitoramento e avaliação do Programa de Erradicação do Trabalho Escravo. Rio de Janeiro: RAP - Revista de Administração Pública 42 (5): 792-828, SET./OUT. 2008.

ARAÚJO, A. R. 0 assédio moral organizacional. São Paulo: LTR, 2012. 
ARISTOTELES. Politics: Books I, II and III. Tradução: W.E BOLLAND, M. A. Londres: Kessinger Publishing, 1877.

BALDIN, N.; MUNHOZ, E. M. B. Educação Ambiental Comunitária: Uma experiência com a técnica de pesquisa Snowball. REMEA - Revista Eletrônica do Mestrado em Educação Ambiental, n.01, v. 27, 2011, p. 46-60.

BALES, K.; ROBBINS, P. T. No one shall be held in slavery or ser-vitude: a critical analysis of international slavery conventions. Human Rights Review, 2, 2001. Disponível em: <http://oro.open.ac.uk/5033/1/Bales_and_Robbins.pdf>. Acesso em: 18 mar. 2020.

BARELLI, Walter; VILELA, Ruth. Trabalho escravo no Brasil: depoimento de Walter Barelli e Ruth Vilela. Est. Avançados, USP, n. 38, 2000, p. 7-29.

BARRETO, Margarida. HELOANI, Roberto. Violência, saúde e trabalho: a intolerância e o assédio moral nas relações laborais. Serv. Soc. Soc., São Paulo, n. 123, p. 544-561, jul./set. 2015.

BASTOS, S. O. A definição de trabalho escravo contemporâneo: Em busca da unidade conceitual semântica e ontológica para além da ciência jurídica. UFMG, Faculdade de Direito: monografia de graduação, 2016.

BRASIL. Código Penal Brasileiro. Decreto-Lei no 2.848, de 7 de dezembro de 1940. Disponível em: <https://www.jusbrasil.com.br/topicos/10621211/artigo-149-do-decretolei-n-2848-de-07-de-dezembro-de-1940>. Acesso em: 20 jun. 2018.

BRITO FILHO, J. C. M.; CARDOSO, Y. S. S.; LITAIFF, A. R. M. Trabalho em condições degradantes - caracterização: análise da jurisprudência do TRT/8 a região e do TRF/1 ${ }^{a}$ região. Revista Direitos, Trabalho e Política Social, UFPA, Cuiabá, n. 4, 2017, p. 40-67.

BRYMAN, A. Social Research Methods (3aㅗ ed.). Oxford: Oxford. 2008.

DEJOURS, C . Travail, usure mentale. Paris: Bayard, 2000.

DESPENTES, Virginie. Teoria King Kong. São Paulo: Editora N-1. 2016.

FIGUEIRA, R. R. Por que o trabalho escravo? Est. Avanç., São Paulo, n. 38, 2000, p. 31-50.

FIGUEIREDO, D.; NASCIMENTO, F.; RODRIGUES, M. E. Discurso ao corpo e identidade: representações do corpo feminino em Revistas brasileiras. Ling. (dis)curso, Tubarão, n. 1, 2017, p. 67-88.

FLICK, U. Qualidade na pesquisa qualitativa. Porto Alegre: Artmed. 2009. 
GOMES, A. M. de C. Repressão e mudanças no trabalho análogo a de escravo no Brasil: tempo presente e usos do passado. Revista Brasileira de História. São Paulo, v. 32, no 64, p. 167-184 $-2012$.

LEÃO. L. H. Da C. Trabalho escravo contemporâneo: a construção social de um problema público no norte fluminense. UFRGS - Universidade Federal do Rio Grande do Sul: Psicologia \& Sociedade, 2015.

MANZINI, E. J. Entrevista semi-estruturada: análise de objetivos e de roteiros. In: Seminário internacional sobre pesquisa e estudos qualitativos, Bauru, 2004. A pesquisa qualitativa em debate. Anais. Bauru: USC, 2004. CD-ROOM. ISBN: 85-98623-01-6. 10p.

MARINHO, M. O. e VIEIRA, F. O. A jornada exaustiva e a escravidão contemporênea. Cad. EBAPE.BR, Rio de Janeiro, n. 2, 2019, p. 351-361.

MARTINEZ, F. J. De menina a modelo, entre modelo e menina: gênero, imagens experiência. Tese de Doutorado. Instituto de Filosofia e Ciências Humanas. Universidade Estadual de Campinas. Campinas, 2009.

MASCARENHAS, A. O., DIAS, S. L. G., BAPTISTA, R. M. Elementos para discussão da escravidão contemporânea como prática de gestão. Revista Administração de Empresas, 2015, v.55, n.2, pp.175-187.

MELO, L. A. C. Premissas para um eficaz combate ao trabalho escravo. Rev. do Ministério Público do Trabalho, Brasília, n. 26, 2003, p. 11-33.

MESQUITA, G. L. Ser top model no Brasil: reflexões à luz da legislação trabalhista. Lacier, Campinas, 2017, p. 1-10.

MTE. Erradicação do Trabalho Escravo de 2016. Disponível em: <http://trabalho.gov.br/fiscalizacao-combate-trabalho-escravo/resultados-das-operacoesde-fiscalizacao-para-erradicacao-do-trabalho-escravo>. Acesso em: 18 jun. 2018.

OIT. Organização Internacional do Trabalho. 0 que é trabalho forçado? Disponível em: <http://www.ilo.org/brasilia/temas/trabalho-escravo/WCMS_393058/lang--pt/index.htm>. Acesso em: 20 jun. 2018.

SALDANÃ, J. The Coding Manual for Qualitative Researchers (2ª ed.). London: Sage. 2013.

SENTO-SÉ, Jairo Lins de Albuquerque. Trabalho escravo no Brasil na atualidade. São Paulo: LTr, 2000.

Tribunal Regional do Trabalho. Submissão do empregado a jornada exaustiva caracteriza trabalho análogo ao escravo. Disponível em: <https://trt- 
3.jusbrasil.com.br/noticias/153074651/especial-submissao-do-empregado-a-jornadaexaustiva-caracteriza-trabalho-analogo-ao-escravo>. Acesso em: 20 jun. 2018.

VAL, A. C.; CARVALHO, M. B.; CAMPOS, R. O. Entre o singular e o coletivo: a experiência de um serviço na abordagem das anorexias e bulimias. Physis, Rio de Janeiro, 2015, n. 1, p. 99-119.

VIANNA, C S. M. Da imagem da mulher imposta pela mídia como uma violação dos Direitos Humanos. Rev. da Faculdade de Direito UFPR, Curitiba, n. 0, 2005, 1-14.

ZYGMUNT, Bauman. Vida para consumo. Rio de Janeiro: Editora Zahar, 2008. 